öz

“(Mimarlkk) Tarih(i)sel Semantik: Karatepe Saçakları'nın Neoliberal Kapitalizm Güdümlü Dönüşümü: The Museum Hotel Antakya" başlıklı makale, isminde adı geçen iki projenin görsel bir karşılaş̧ırması değildir; bunun yanında, iki yapının müellifleri üzerinden bir "star mimarlık" gündemi yaratmaya da çalışmaz. Elinizdeki çalıșma, bir arkitektonik nesne olarak saçağın, takribi 50 yıl içerisinde uğradığı semantik dönüşüm üzerinden, Arolat ya da projenin diğer aktörleri tarafından "icat edilen" Müze-Otel fonksiyonunun, Karatepe'de somutlașan ve "ikonikleșen" arkeolojik koruma saçaklarının neoliberal kapitalist bir tezahürü olup olmadığını tartışmaya açmayı amaçlar. Yani çalışmanın temelinde yatan karşılaştırma, ikisi de kendi zamansal bağlamlarında "ikonik" olarak kabul edilebilecek bu yapıların, içine doğdukları sosyo-ekonomik arka plandır. Diğer bir deyişle, devlet politikalarının tartışmasız yansımaları olan mimarlık ürünleri ve onları var eden iki özgül dönem, neoliberal kapitalist tandanslar sonucu yaşanan semantik dönüşüm özelinde ortaya çıan mimari refleksler bağlamında bir değerlendirmeye tabi tutulmak istenmektedir Özellikle vurgulanmak istenen, mimari refleks benzer olsa dahi 50 yıl içerisinde mimarlığın eklemlendiği mekânsal dönüșümün; saçakların otele çevrilmesinde tezahür ettiği gerçeğidir. Yani 1950'li yılların, saçaklardan oluşan koruma üst örtüsü, 21. yüzyılın başında yerini icat edilmiş bir fonksiyona, bir müze-otele brrakabilmiștir. Mimarlık tarihini nesnelerinin uğradığı anlamsal dönüşümler bağlamında böylesi bir karşılaştırma, meslek literatürü için önemli veriler teșkil edecektir.

Anahtar Kelimeler: Saçak, dönüşüm, neoliberal, bağlam, yer.

\section{(Mimarlik) Tarih(i)sel Semantik ya da Karatepe Saçakları'nın Neoliberal Kapitalizm Güdümlü Dönüşümü: The Museum Hotel Antakya}

(iD) Asli Can

Yeditepe Üniversitesi Mimarlık Fakültesi, Mimarlık Anabilim Dalı, İstanbul, Türkiye

Başvuru tarihi/Received: 28.04.2021, Kabul tarihi/Final Acceptance: 21.09.2021

\section{Extended Abstract}

The Museum Hotel Antakya, whose project is managed by Emre Arolat Architects and whose design and application have been intertwined both intellectually and operationally since 2009 with its compound functions, the unique value of the Ancient Roman ruins it hosts, and unusual construction methods. It can be subjected to different readings in various plural contexts that can be increased. The meaning of the object can be stratified, deconstructed or studied in the context of semantic transformations by considering it from different angles in numerous articles that can be written on the structure in question. Before the construction is completed; there is no doubt that the hotel, which has been widely discussed in the fields of architecture, archeology, conservation and similar areas, will remain on the agenda for a long time after its opening and use.

The article titled "Architectural Historical Semantic: The Neoliberal Capitalism-Driven Transformation of Karatepe Eaves: The Museum Hotel Antakya" is not a visual comparison of these two projects, neither tries it to create a "starchitectural" narrative by mentioning the two architects of the structures. This very study is a comparison of the projects with their socioeconomic background into which these structures, both of which can be considered "iconic" in their own temporal context. were born. In other words, architectural products, which are the indisputable reflections of state policies, and the two specific periods that brought them into existence, are intended to be evaluated within the context of architectural reflexes that emerged with the semantic transformation experienced as a result of neoliberal capitalist tendencies.

The method adopted by the article is chronological. In the study, Karatepe Aslantaş Open-Air Museum, which was built on the background axis of the brutalist architectural products of 1950s Turkey and pronounced as Karatepe Eaves, is introduced as a design object and tried to be understood with its context. Then, before introducing the Museum-Hotel function to the reader, it discusses the reflections of the decisions of January 24, 1980, on architectural production, which brought a total change in Turkey from different perspectives in the early 1980s, which was accepted as the breaking point of the transition to the neoliberal economy and free market that paved the way for its invention. The Museum Hotel Antakya, designed by Emre Arolat Architects; is evaluated in terms of its invented function, context, design criteria, use of materials and features that make it a $21^{\text {st }}$ century architectural icon. The conclusion section, which is designed as an open-ended discussion platform, tries to answer the following question and to put forward various answers and suggestions by problematizing this issue: "Is Eaves' Architectural Manifestation in the $21^{\text {st }}$ Century a Hotel?"

Emre Arolat's architectural reflex includes an understanding that reminds a great deal of the sensitivity of the designers of the Karatepe Eaves. The architects of the two projects trace the "place" in their structures. Even the pilot elements, which are the common point of the projects and can allegorically take on the task of decontextualization, yield to the emphasis of the permission, regardless of whether it is elegant or massive. In other words, the context confronts the experiencer as the most important factor affecting the main decisions in both projects. The common point of these two designs, made 50 years apart, undoubtedly stems from the strength of their context. Two clusters of remains were not moved to the museum in line with the opinions of the experts, instead an in-situ conservation approach was adopted. However, 50 years ago, the protection approach of various historical and archaeological remains was a top cover that could not compete with it, today this top cover can easily evolve into a world brand hotel, which is a rent-based product.

The aim of the article is far from criticizing the architectural production of EAA or focusing on a social perspective on the pros and cons of the neoliberal system. What is particularly emphasized is the spatial transformation in which architecture has been articulated in 50 years, even if the architectural reflex is similar; it is the fact that the eaves are manifested in the conversion of the hotel. In other words, the protection top cover of the 1950s, consisting of eaves, was replaced by an invented function, a museum-hotel, at the beginning of the $21^{\text {st }}$ century. Such a comparison in the context of the semantic transformations of architectural history objects will constitute important discussion fields for the literature.

Keywords: Eaves, transformation, neoliberal, context, place. 


\section{Giriş}

Emre Arolat Architects tarafindan projesi yürütülen ve tasarım ve uygulamasının iç içe geçmiş ilişkisi hem düşünsel hem de operasyonel anlamda 2009 y1lından beri devam eden the Museum Hotel Antakya gerek bileşik fonksiyonlarının biricikliği gerek ev sahipliği yaptığı Antik Roma kalıntılarının benzersiz değeri gerekse alışılmışın dışında inşa yöntemleri ve benzeri örnekleri artırılabilecek muhtelif çoğul bağlamlarda farklı okumalara tabi tutulabilir. Söz konusu yapı üzerine yazılabilecek sayısız makalede, nesnenin anlamı, birbirinden farklı açılardan ele alınmak suretiyle katmanlaştırılabilir, yapı-sökümüne uğratılabilir ya da anlamsal dönüşümler bağlamında incelenebilir. Henüz inşaatı tamamlanmadan; mimarlık, arkeoloji, koruma ve benzeri alanlarda çokça tartışılan otelin, açılışı yapıldıktan ve kullanımı yürürlüğe girdikten sonra da uzun süre gündemdeki yerini koruyacağı şüphesizdir.

“(Mimarlk) Tarih(i)sel Semantik: Karatepe Saçakları'nın Neoliberal Kapitalizm Güdümlü Dönüşümü: The Museum Hotel Antakya" başlıklı makale, isminde adı geçen iki projenin görsel bir karşılaştırması değildir; bunun yanında, iki yapının müellifleri üzerinden bir "star mimar" anlatısı oluşturmaya da çalışmaz. Tartışmaya açılan projelerin eklemlendiği arkeolojik kültür kalıntılarının koruma konseptleri bağlamında değerlendirilmesi de başka bir bilim dalı çalışmasının konusudur. Mimari artifaktlar olarak bu kalıntıların içlerine doğdukları tarihsel arka planlar; yani muhtelif bir Hitit-Roma mimarlık üretimlerinin karşıllaştırma denemesi ise bu makalenin odağının çok dışında, hatta belki de teknik olarak imkansızdır. Bu sebeple gerek kalıntıların fiziksel bağlamları gerekse tarihsel özellikleri, bir karşılaştırmaya tabi tutulmadığ gibi, muhtelif başka ve çok geniş araştırma konularına ait olduklarından dolayı, makalenin dışında bırakılmıştır.

Elinizdeki çalışma, bir arkitektonik nesne olarak saçağın, takribi 50 yıl içinde uğradığı semantik dönüşüm üzerinden, Arolat ya da projenin diğer aktörleri tarafindan "icat edilen" Müze-Otel fonksiyonunun,
Karatepe'de somutlaşan ve "ikonikleşen" arkeolojik koruma saçaklarının neoliberal kapitalist bir tezahürü olup olmadığını tartışmaya açmayı amaçlar. Yani çalışmanın temelinde yatan karşılaştırma, ikisi de kendi zamansal bağlamlarında "ikonik" olarak kabul edilebilecek bu yapıların, içine doğdukları sosyo-ekonomik arka plandır. Diğer bir deyişle, devlet politikalarının tartışmasız yansımaları olan mimarlık ürünleri ve onları var eden iki özgül dönem, neoliberal kapitalist tandanslar sonucu yaşanan semantik dönüşüm özelinde ortaya çıkan mimari refleksler bağlamında bir değerlendirmeye tabi tutulmak istenmektedir.

Makalenin benimsediği yöntem kronolojiktir. Çalışmada önce 1950'ler Türkiye'sindeki brütalist tandanslı mimarlık ürünlerinin oluşturduğu arka plan ekseninde inşa ve Karatepe Saçakları şeklinde telaffuz edilen Karatepe Aslantaş Açıkhava Müzesi, bir tasarım nesnesi olarak tanıtılır ve bağlamı ile anlaşılmaya çalışılır. Ardından okuyucuya Müze-Otel fonksiyonu açıklanmadan önce, onun icadının yolunu açan neoliberal ekonomi ve serbest piyasa ekonomisine geçişin kırılma noktası olarak kabul edilen 1980'li yılların başında Türkiye'yi farklı açılardan topyekûn bir değişime uğratan 24 Ocak 1980 kararlarının mimarlık üretimi üzerindeki yansıması değerlendirilir. Emre Arolat Architects tarafindan tasarlanan The Museum Hotel Antakya; icat edilmiş fonksiyonu, bağlamı, tasarım kriterleri, malzeme kullanımı ve onu bir 21. yüzyıl mimari ikonu olma yolunda öne çıkartan diğer muhtelif özellikleri bağlamında ele alınır. Ucu açık bir tartı̧̧ma platformu şeklinde kurgulanan sonuç bölümü, özünde; "Saçak'ın 21. Yüzyıldaki Mimari Tezahürü Otel midir?" sorusuna cevap vermeye çalışmakta; bu sorunsalı çeşitli başka unsurlarla problematikleştirerek ortaya muhtelif cevap ve öneriler atmayı denemektedir.

\section{Saçak}

Saçak, çatının yapının dışına taşan kısmıdır (Hasol, 1998). Genelde binanın duvarlarını yağmurdan korumak amaciyla kullanılır. Saçakların ana fonksiyonu yağmur suyunu 
duvardan uzak tutmak ve çatının duvar ile birleștiği noktalarda su birikmesine engel olmaktır (vikipedi). İkincil kullanım amacı güneş ışığını kontrol etmek olan saçak, yapının fonksiyonel bir bileşeni olarak kabul edilebilir.

Saçak, geleneksel bir yapı elemanı olarak Türk Evi ile özdeşleştirilir. Burkut (2019), saçakların, Osmanlı/Türk evlerinin karakteristik özelliklerinden biri olduğunu vurgularken, söz konusu bileşenin hem pilanimetri hem de cephe hakimiyeti bağlamında önemli bir unsur olduğuna dikkat çeker. Burkut'a göre saçaksız Türk Evi yoktur denilebilir. Türk Evi'nde saçaklar oldukça geniş tutulmuştur ve çoğunda saçak altı kaplaması yoktur. Genellikle köşelerde yuvarlatılmış olan saçaklar çıkmalarla gittikçe genişleyerek sokak üzerinde bir saçak altı oluşturmaktadır. Türk Evi'nin planı ve cumbanın konumu çatı ve saçakları şekillendirmiştir (Burkut, 2019).

Osmanl1/Türkiye mimarlık tarihinde saçak, yalnızca fonksiyonel ya da operasyonel bir anlam içermez. Türk Mimarisinin kimliksel bir aidiyet unsuru olarak saçağın cephede tanımladığı vurgu, mimarlar tarafından, tarihin tüm Milli Mimari dönemlerinde kullanılagelmiştir. Bu bağlamda göstergesel bir temsiliyet yüküne sahip olan söz konusu yapı eleman1, keskin bir yerinden edilmeye maruz kalır. İki ya da üç katlı ahşap Türk Evleri'nin çatısından koparılan saçak, 20. yüzyıl başına tarihlenen Birinci Ulusal Mimarlık döneminin cephe örüntüsünün en güçlü unsurlarından biri olarak, postane, okul, iskele gibi Geç Osmanlı Döneminin önemli binalarına eklemlendirilirken, 1930'lu yılların ortalarından 1940'ların sonuna uzanan ve Sedad Hakk1 Eldem' in “Taş Devri”" olarak adlandırdığı İkinci Ulusal Mimarlık akımının büyük boyutlu fakülte, radyo evi, adalet saray1 ve benzeri devlet temsili güçlü binalarda yerini alır. Binaların boyutu büyüdükçe saçak, sudan koruyucu özeliğini yitirirken, gittikçe göstergesel bağlamda bir dekor, bir temsiliyet nesnesi ya da bir kimliklendirme unsuruna dönüşür. Öyle ki Paul Bonatz'ın Ankara'da inşa ettiği Saraçoğlu Mahallesi'nin konutlarında saçak, aynı kendisi gibi işlevsizleșmiş olan çıkmaların üzerini örterken, fonksiyonel bağlamda içi boşalsa da oldukça güçlü bir anlambilim imgesine dönüşür.

$\mathrm{Bu}$ makalenin başat konusu olan ve Karatepe Aslantaş Açık Hava Müzesi, diğer adıyla Karatepe Saçakları projesi, saçak elemanının özgün fonksiyonuna sahip çıkarak, diğer yandan onu bağlamından koparıp mimari bir artifakta dönüştürmesi sebebiyle özel olarak tartışmaya açılmalı ve semantik bir okumaya tabi tutulmalıdır. Tasarım başlangıcı 1957 ve ilk etap uygulamalarının tamamlanması 1961 yılına tarihlenen saçakların üslupsal yaklaşımını analiz etmeye çalışırken dikkatli olmak gerekir. Genel olarak her mimari ürün için akılda tutulması gereken asıl mesele, bir yapının yalnızca bir tandans ya da stil bağlamında değerlendirilmesinin ancak kısır okumalar doğuracağ lamda, Karatepe Saçakları'nın ilk bakışta göze çarpan etkileyici brütalist kütleleri, daha yakın bir incelemeye tabi tutulduğunda eleştirel bölgeselci özellikler gösterir; pilotilerin topografyaya gösterdikleri saygı duruşu, brüt beton saçak elemanlarının asimetrisi, havada uçma hissinin yer bağlamı ile kurduğu çatışmalı ilişki ile alternatif ve ezber bozucu bir hikâye anlatır. $\mathrm{Bu}$ anlatı, öncelikle, söz konusu zaman aralığında Türkiye'nin içinden geçtiği mimari dinamikler bağlamında değerlendirilmelidir.

İkinci Dünya Savaşı, 1945 yılında Almanya ve müttefiklerinin kesin bir yenilgisiyle sonuçlanır. Modern zamanların en travmatik krizi olarak nitelendirilebilecek bu toplumsal hadise, kaçınılmaz olarak dünyadaki tüm dinamikleri yerinden eder. Politik, sosyolojik, ekonomik ve kültürel tüm dengelerin değiştiği yeni dünyada, söz konusu dengelerin üçüncü boyuttaki yansıması olarak nitelendirilebilecek mimarlık üretiminin de semantik ve morfolojik bir değişime uğraması kaçınılmazdır. Mimarlık pratiğinde ürünlerini ancak 1950'lerde vermeye başlayacak olan bu yeni kültürel anlayış, yansımalarını şüphesiz Türkiye'de de bulur.

İkinci Dünya Savaşı sonrası Amerika ve Avrupa'daki mimarlık üretimi, büyük 
boyutlu, anıtsal ve ulusalcı göstergelere sahip milli mimarlık dönemi yapılarına bir tepki olarak modernizmi yeni baştan inşa eder. Nazi Almanya'sindan Amerika'ya kaçan Walter Gropius ve Ludwig Mies van der Rohe gibi mimarların Bauhaus ekolünü yanlarında taşımaları ve onu savaş sonrası ortaya çıkan fonksiyonlara uygulayıp yeni bir rasyonalist mimarlık anlayışı ortaya koymuş olmalarının yanında Le Corbusier'nin Avrupa'da tekrar keşfedilişi, organik mimarlık arayışlarıyla döneme damga vuran Frank Lloyd Wright, Louis Kahn gibi isimlerin parlaması söz konusu pratik için yeni bir dönemin başlangıcı anlamına gelmektedir. Bu sebeple 1950'ler, o güne kadar katılaşmış muhtelif mimarlık anlatılarından; rasyonel, çoğulcu ve serbest bir üretim alanına geçiş bağlamında bir dönüm noktası olarak kabul edilebilir.

Türkiye, İkinci Dünya Savaşı'nın sonunda, İngiltere ve Fransa'nın yanına müttefik olarak eklemlenir ve Almanya'ya kâğıt üzerinde savaş ilan eder. Bu politik yeniden konumlanma, Amerika'dan alınan Marshall yardımı ve NATO üyeliği gibi gelişmeleri beraberinde getirir. Bunun yanında, dünyada artık Milli Şeflikler döneminin kapanmış olması dolayısıyla Türkiye'de de CHP güdümlü tek parti iktidarı yerini 1946 yılında çok partili sisteme, aynı yıl yapılan ilk çok partili seçime ve nihayet 1950 yılında DP iktidarına bırakır.

Sözü edilen politik katalizörlerin ilk yansıması ekonomik bağlamda gözle görülür hale gelir. "İktisadi hayatta özel teşebbüs ve sermayenin faaliyeti esastır," sloganiyla iktidara gelen DP, hükümet programında yer alan "iktisadi ve mali görüşlerimizin esas1, bir taraftan devlet sektörünü mümkün olduğu kadar daraltmak, hususi teşebbüs sahasını mümkün olduğunca genişletmek şeklinde ifade olunabilir," sözleriyle liberal-kapitalist düşüncenin yolunu açarken, bir yandan da seyreltilmiş devletçiliği haber verir.

Tüm bu unsurlar, Türkiye'deki mimarlık üretimini geri dönülemez biçimde dönüştürür. İkinci Dünya Savaşı'ndan sonra Avrupa ve Amerika'da hızla gelişen mimari akımlar, bu dönemde ithal olanak- ların çoğalması sayesinde getirilen yabancı mimarlık dergilerinin çoğalmasıyla Türkiyeli mimarların üretim ve pratiklerini temelden etkiler. Bu benimseme safhasının önemli bir altyapı etkeni de savaş sonrasında Türkiye ve Almanya arasındaki politik ve kültürel ilişkinin yön ve biçim değiştirmesi, bu sebeple artık salt Alman kültürel ortamının yansıması dışında, diğer ülkelerdeki gelişmelerin de Türkiye'de tartışılmaya ve sonuçlarının değişik yollardan izlenmeye başlanmasıdır. Bu gelişmelerden biri tartışmasız olarak, Brütalizm'dir.

Erkol (2016), brütalizmi, 1950'lerde ortaya çıkmış ve giderek uluslararası nitelik kazanmış bir modernizm revizyonu olarak yorumlar. Ona göre Modern Mimarlığın bir uzantısı olarak değerlendirilen Brütalizm temel ilkesi yapının strüktürünü ve malzemesini olduğu haliyle, açıkça ortaya koymaktır. Kaplamasız yüzeylerle malzemenin gerçek dokusunun gösterilmesi amaçlanır. Brüt beton bu akımın vazgeçilmez malzemesi olur, çünkü kaplamalardan ve işlenmişlikten vazgeçmenin göstergesidir. Beton malzeme, kalıp izleri ile birlikte olduğu gibi görünür kılınır. Erken modern dönemde çoğunlukla iç mekânda kullanılan ahşap malzeme de dış cephede yer almaya başlar. Betonun patinası, ahşabın budakları, demirin pası ve benzeri her öge malzemenin doğal halini gösterdikleri için değerlidir (Erkol, 2016). Yapılarda teknik mükemmellik yerine dogallık, kendi kendine olmuşluk, hatta biraz da hamlık arandığı, aynı işlevleri taşıyan birimlerin görsel bütünlügünün sağlanması ve diğer bütünlüklerle ayrımının okunaklı kılınmasıyla oluşturulan parçalı kütle, vurgulanmış konstrüksiyon, malzemenin çıplaklı̆̆g/yalınlığı, kimi defa gelişmiş teknolojinin strüktür ve ayrıntılarda sergilenmesi gibi özellikleri içeren uygulamaların bütünü Brütalist Üslup olarak isimlendirilir (Akın, 2004). Tüm bu özelliklerin yanında brütalist binalarda en çok aranan özelliklerden biri, doksan derecelik cetvele uygunluktur denilebilir (Özer, 2000).

Türkiye'de Brütalizm, alışıldık olarak Altuğ-Behruz Çinici'nin simgesel projeleri olan Orta Doğu Teknik Üniversitesi kam-

114 Sayı 34, Kasım 2021 
Resim: I

Hititlerden kalma duvar buluntusunu örten saçaklar.

Resim: 2

Kazı Evi.

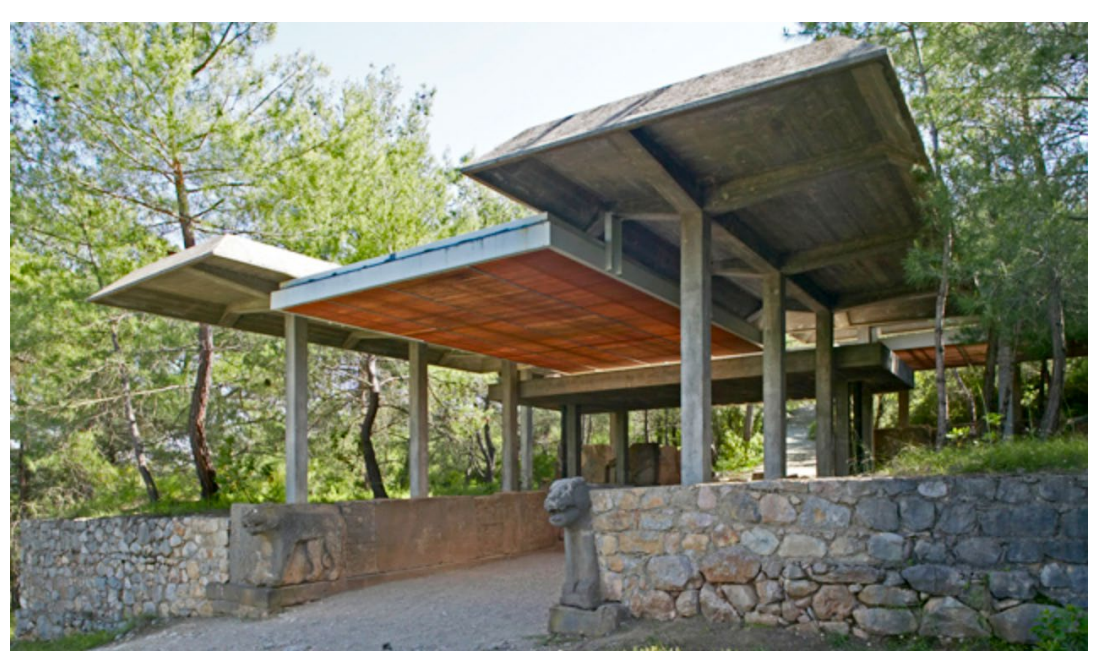

pus binaları ya da Turgut Cansever'in Türk Tarih Kurumu yapısı üzerinden okunabilir. Karatepe Saçakları'nın bu bağlamda söz konusu projelerden işlev, boyut ve en önemlisi mimari refleks olarak ayrıldığ 1 şüphe götürmez bir gerçektir.

Karatepe Saçakları, Karatepe Açıkhava Müzesi için tasarlanmış bir çeşit üst örtü olarak kabul edilebilir. Müellifinin kim olduğu konusu uzun tartışmaları beraberinde getirmekle birlikte, Aykut Köksal (2016) tarafindan yayımlanan Karatepe Saçakları ve Müelliflik Sorunu adlı metinde konuya nokta konur: projenin tasarım müellifi İtalyan Mimar Franco Minissi; projeyi yere uygun biçimde yeniden kotlandırarak uygulama projesini çizen ise Turgut Cansever'dir. Karatepe Saçakları, Cansever'in



sonraki üretimi için ilham verici bir kaynak olmuş, saçakların sunduğu yeni mimari dağarcık Cansever yapılarında sıklıkla karşımıza çıkmıştır (Köksal, 2016). Bununla birlikte müelliflik tartışması bu çalışmanın kapsamı dışında kalmaktadır. Bu sebeple saçakların kendine özgü mimarisi, iki müellifin mimari tandansları bağlamında değil, ortaya çıan son ürünün karakteristikleri üzerinden okunacaktır (Resim 1).

Karatepe Saçakları, Geç Hitit dönemi (MÖ 9-7. yüzyll) buluntularını barındırmak üzere Karatepe milli Parkı içerisinde konumlanır. Tasarım, antik kentin kuzey ve güney girişindeki saçaklar ve arkeolojik alanda çalışan araştırmacıların konaklayabileceği kazı evinden (Resim 2) oluşur. Brüt beton strüktürler hem gün 1şığına çıkarılan eserlerle hem de topografya ile etkileşim içerisindedirler. Saçaklar, buluntuların iz düşümlerini takip eder ve strüktür, kendisini doğa ve buluntularla bir bütün olarak algilatır (Sayin, 2004).

Tanyeli'ye göre Karatepe'yi gerçekten önemli kılan şey, onun alttaki binlerce yıllık yapının bütün biçimlenme anomalilerini, bütün geometri bozukluklarını üstte bir defa daha gündeme taşıyan o ortogonallik yoksunluğudur (Tanyeli, Yücel, 2007). Hitit dönemi yapılarının önemli bileşenleri olan duvarların izi, asimetri göze alınarak, saçaklardan sürülebilir (Resim 3). Özer'in (2000) vurguladığı doksan derecelik cetvele uygunluk kuralı burada son derece cesur bir kararla bozulur; bu bozulmayla ortaya çıkan asimetri, cüretkâr tavrıyla saçakların ezberini bozarken, diğer yandan onu biricikleştiren en önemli karakteristiklerden biridir. Bağlam ile kurulan ilişki, belki de hiçbir brüt beton ihtiva eden projede böylesi bir kesinlikle ortaya konulmamıştır. Brütalizmin çarpıcı dili, malzemenin çıplaklığında kendini var eder. Söz konusu malzeme seçiminin doğaya eklemlenme biçimi, onu, üslubun, yukarıda değinmiş olduğumuz, doğallık, kendi kendine olmuşluk ve hamlık özelliklerini onaylar niteliktedir. Mimar(lar), Adana Karatepe Açıkhava Müzesi tasarımını meydana getiren saçakları ve onların betonarme strüktürün geçmişe ve geleceğe doğru olan 

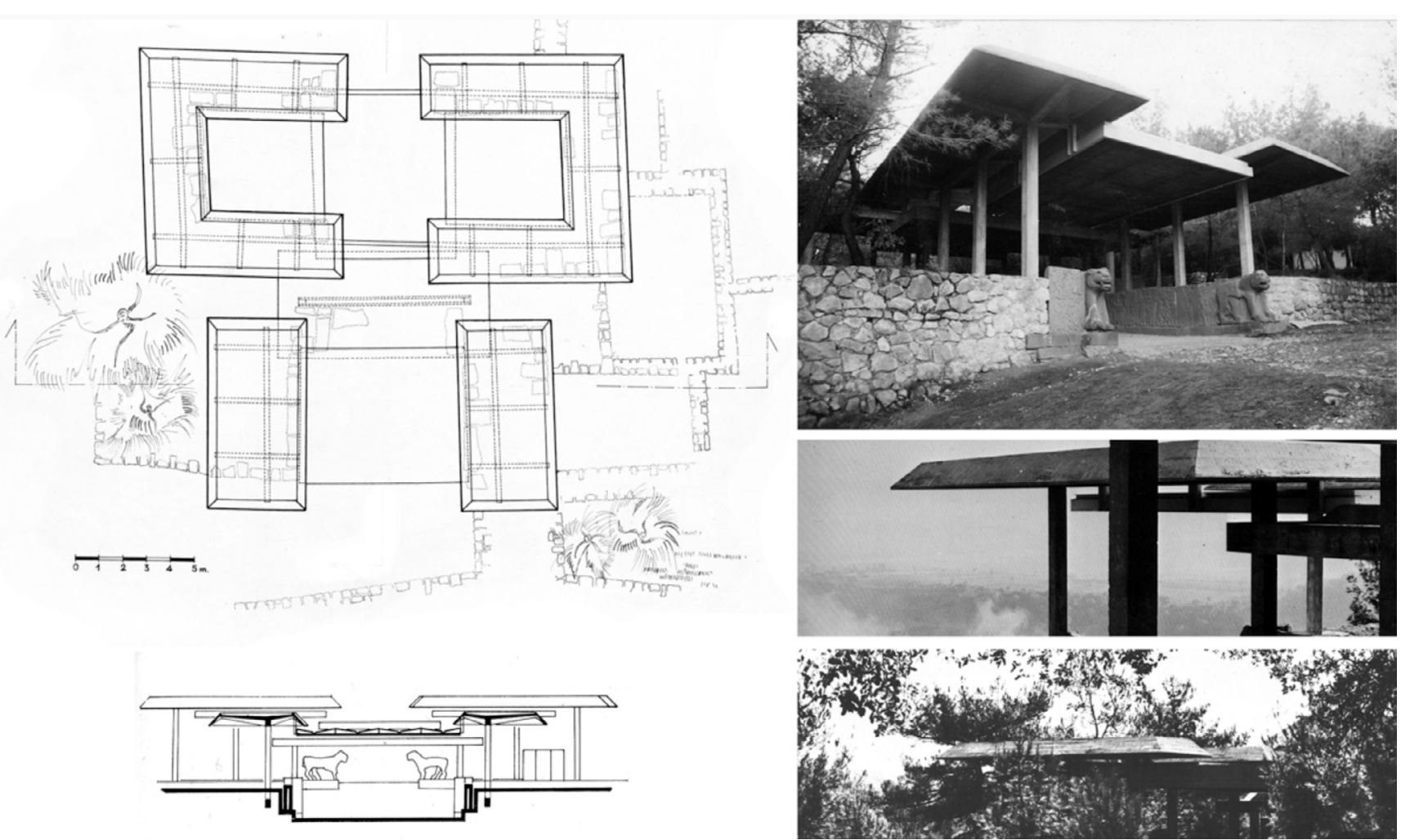

uzanımının yerin ruhu ile diyaloğa girerek bütünleşmesinin, arkitektonikleșmesinin önünü açıp, onları, in situ kalıntılar ile boy ölçüşmeye kalkmadan, ancak varlıklarını da daimî bir şekilde hatırlatarak var oluşun çelişkili doğasını cüretkarca öne çıkarırlar (Ceylan, 2014).

Tüm bu yorum ve değerlendirmeler dahilinde, projede, eleştirel bölgeselciliğin izleri rahatlıkla sürülebilir. Tsonis ve Lafaivre'e göre, post-modernizme bir alternatif yaratma çabası olarak öne çıkan tandans, bölgeselcilik terimini geçmiş zamanlarda kullanıldığı şekliyle duygusal, akıl dışı, önyargılı anlamından ayırmayı ve milliyetçi çağrışımlardan farklı bir şekilde kullanmayı amaçlar (Demirgü̧, 2006). Frampton, eleştirel bölgeselciliği, geleneği ve yerelliği yok sayan modernizme karşı bilinçli bir tepki olarak tanımlar. Frampton'a göre eleştirel bölgeselciliğin ortaya çıkmasındaki en önemli faktörlerden biri kültürel, ekonomik ve politik özgürleşmeye duyulan istektir. Eleştirel bölgeselcilik üzerine yazılarında küreselleşmeyi ve buna bağlı olarak ortaya çıkan aynılaşmayı eleştiren Frampton, eleştirel bölgeselcilik yaklaşımı ile kültürel değerleri tutarak evrensel uygarlık içinde yer alınabileceğini öne sürer (Erkol, 2016).

Modernizmin evrensel mimarlık söyleminin yenilenmesine ihtiyaç duyulan dönemde bölgeselci yaklaşım kendine önemli bir yer bulur. Bu dönemde bağlam, bellek, kimlik üzerinden tartışmalar yapılmış, "yer"in özellikleri ortaya konmaya çalışılmıştır (Erkol, 2016). Tam da bu sıfatlar üzerinden Karatepe Saçakları'na yöneltilen bir okuma, Le Corbusier'nin “yer”den hem fiziksel hem de alegorik bir kopuş anlamı ihtiva eden pilotilerinin, projedeki incecik kesitlerinin (Resim 4) ortaya koyduğu büyük bir zarafetle yükselirken, öte yandan topografyaya duydukları saygı ile "yer" ile girilen aşkın ilişkiyi gözler önüne serer.

Saçak ögesinin yukarıda bahsettiğimiz kimlik ve aidiyet temsili burada anlam içine sıkışıp kalmaz. Türk Evi'nden koparılarak bağlamı değiştirilmiş saçakların fonksiyonu değişmez. Bunun yanında tamamen değiştirilen malzemenin biçim ile kurduğu benzersiz ilişki, saçakların varlığını bambaşka bir “oluş”a dönüştürür. Bu da kimliğin barındırdığı tüm semantik
Resim: 3

Karatepe saçakları, plan, kesit ve muhtelif fotoğraflar. 


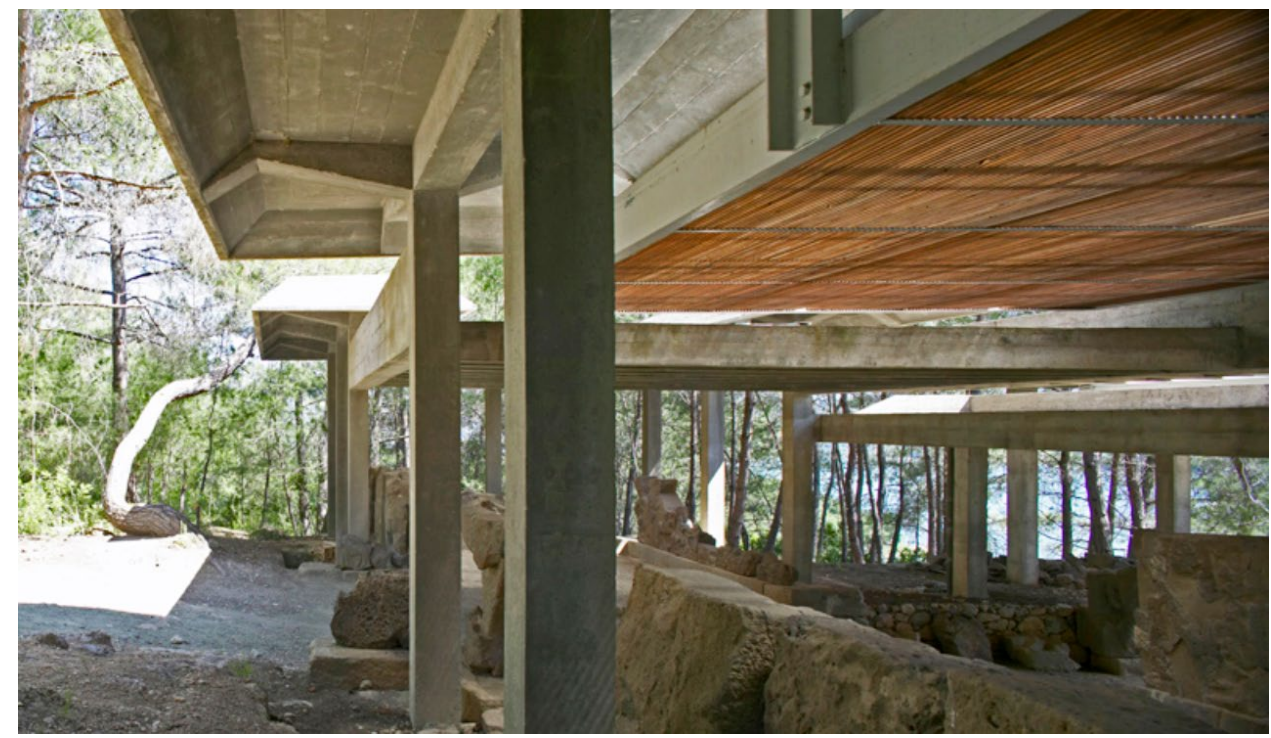

özellikleri serbest bırakır, saçakların izleyici ile özgürleştirici bir ilişki kurmasını sağlar. Zira Bölgeselci mimari kullanıcısıyla doğrudan iletişim kurar. Dağarcığında yere dair veriler barındırdığı için bireyde tanışıklık ve aidiyet hissini kolayca kurabilir. Modernizmin yabancı olma halinin tam zıddıdır ve bu nedenle de hızla benimsenmiştir (Erkol, 2016).

Eleştirel bölgeselcilikte deneyim ön plandadır. Bu nedenle ışığın yanı sıra sıcaklık, hava sirkülasyonu, yap malzemelerinin mekâna yaydığı kokular, dokuları hatta kimi zaman sesleri mekânsal algıyı değiştirir. Bütün bu faktörleri gözeterek sonunda coğrafyaya ve kültüre ilişkin verileri gözeten, mimarlığın tektonik ifadesi ile birleşen ve bireyin tüm duygularına hitap etmeyi hedefleyen, bulunduğu yere ait bir mimari önermektedir (Erkol, 2016). Nevzat Sayın'a (2004) göre, Açık Betonun yanı sıra çelik, cam, ahşap da aynı duyguyu taşır. İçlerinden geçen ve geçemeyen 1şıklarla ve birbirinden koparak duruşları yüzünden içlerinden geçen rüzgarla anlaşılır olmak gibi bir özellikleri vardır. Bu denli tasarlanmış ve betonarme gibi özgül ağırlığı yüksek bir malzemeden yapılmış olan saçakların varla yok arasındaki hali, Sayın (2004) tarafindan çok etkileyici olarak yorumlanır.

Bağlamına uyum sağlayan, "yer" ile doğrudan ilişki kuran, katılaşmış, kristalize olmuş kimlikleri reddeden ve çok katman-
11 anlamlar silsilesini var eden Karatepe Saçakları, çok katmanlılık ve anlamlılığına ithafen, herhangi tek bir üslup altında değerlendirilemez. Böylesi bir okuma çabası projeyi eksiltir, biricikliğini ortadan kaldırır. Saçakların, Türkiye Mimarlık tarihinde yapılabilecek en ezber bozucu değerlendirmelere rahatlıkla tabi olabileceğini, özellikle eleştirel bölgeselcilik ekseninde, eleştirinin nesnesini devamlı bir krize uğrattı̆̆ını hatırlayarak, söylemek, bu bağlamda, hiç de yanlış olmayacaktır.

\section{Otel}

24 Ocak 1980 kararları ile Türkiye'de yaşanan keskin dönüşüm, kuşkusuz yalnızca bu ülkeye özgü değildir. Dünyanın genel konjonktürünün 80'li yıllarda ciddi ve kalıcı bir farklılaşmaya uğradığını söylemek bu bağlamda olukça mümkündür.

EAA tarafindan tasarlana The Museum Hotel Antakya'yı analiz etmeden önce, Türkiye'nin bugün içinde bulunduğu ve mimarlıkta da kaçınılmaz olarak karşı1lığını bulan post-kapitalist çarkın orijinlerine dönmek ve çalışmada 1980'li y1llara dair bir değerlendirmeye yer vermek bu bağlamda oldukça zaruridir.

Türkiye'nin tarihi boyunca yaşadığı en büyük ekonomik dönüşüme karşılık gelen 80'li yıllar, 24 Ocak 1980 kararları ile neoliberal politikaların hüküm sürmeye başlayarak kapitalizmi güçlendirmesi şeklinde telaffuz edilir. İthal ikameci politika- 
lardan ihracata dayalı bir sanayi modeline geçiş şeklinde ifade edilebilecek bu kırılma, yalnızca üretim biçimleri ya da finansal istatistiklerde değil, kaçınılmaz olarak kentsel mekân ve inşaat pratiklerinde de kendini gösterir. Devletin teftiş mekanizmalarının piyasayı terk etmesi ile neoliberal kapitalizm kendisine rahatça hareket edebileceği bir alan bulur. $\mathrm{Bu}$ alan hem üretim biçimleri ve ekonomik işleyişler bağlamında metaforik hem de kentsel dönüşüm düzeyinde okunduğunda fizikseldir. Neoliberal kapitalizm kentsel mekânın üretilmesinde kendi politikalarını oluş̧urur (Uğurlu, 2013).

David Harvey (1997), kentleşmenin, kapitalizmin tarihi boyunca sermaye ve emek fazlasını sağlayan kilit yöntemlerden biri olduğunu iddia eder. Özellikle yapısal krizleri çözme dinamiklerinin zayıfladığı dönemlerde mekân, kapitalizm için kriz çözücü araçlardan biri olarak değer kazanır (Uğurlu, 2013). 80ler boyunca ve sonras1 değerlendirmelerde kentsel dönüşümler üzerinden okunan bu artı ürün yaratma biçiminin, yabancı sermaye destekli büyük ölçekli özel fonksiyonlu yapılar tarafından değerlendirilmesinin de zaruri olduğu bir gerçektir. Bu yapılar değerlendirilirken, aynı ulus inşası serüvenlerinde olduğu gibi, devletin, bu defa da yeni üretim biçimleriyle temsil edildiği gerçeğinin unutulmaması gerekir. 80ler, ortaya çıkan yeni yapı fonksiyonları ile değişen morfolojlier üzerinden de kritik anlamda değerlendirilebilir.

Neoliberal sosyo-ekonomik arka planın mimarlık tezahürü, Lefebvre'in (2014) "Üretim tarzı, bazı toplumsak ilişkilerle birlikte kendi mekânını [ve zamanını] örgütler," cümlesi üzerinden rahatlıkla okunabilir. Mekânsal pratikler bu temsiller ile toplumsal ilișkiler arasındaki etkileșim sonucunda oluşurlar. Önemli olan, mekânın kapitalist toplumda nasıl üretildiği ve bu üretim sürecinde ortaya çıkan çelişkilerin analizidir. Kapitalizm için mekânın somut kullanım değeri değil, soyut yani değişim değeri önemlidir. Somut mekân kavramı günlük yaşam pratiklerimizi gerçekleştirdiğimiz, üzerinde yaşamımızı sürdürdüğümüz, ihtiyaçlarımızı karşıladığımız ve kullanım değerine sahip bir mekâna işaret etmektedir. Soyut mekân kavramı ise mekânı fiziksel bir parsel olarak kullanım değeri olarak değil, üzerinden kâr ve rant sağlanacak bir araç olarak görmektedir. Mekânın tarihsel üretimi, kullanımı ve temsil ettiği sosyal değerlerin kendi başına önemi yoktur. Bunlar ancak söz konusu mekânın değişim değerine katkıda bulundukları sürece önemlidir (Lefebvre, 2014).

Lefebvre (2014) kapitalin ürettiği mekânın en temel niteliğini çelişik olmasında bulur. Ona göre kapital, yalnızca araçsal, nesneleşmiş bir mekân üretmez. Yani mekânı yalnızca hedeflerine, amaçlarına ulaşmak adına kullanmaz. Gerektiğinde mekân tıpkı para ve metalar gibi soyutlamalardan biridir. Bilgiye benzer. Nesneyi de araçları da aşan bir yönü vardır. Bu nedenle mekân bir üretimdir. Onu yalnız içine kapalı, şizofren bir bilinç gibi tasarlamak onun doğasını yıkmaktır. Mekâna en kökensel yaklaşım toplumsal olmalı ve onun toplumsal üretimine yönelmelidir (Kurtar, 2013).

Birbirinden çok farklı tarihsellikleri olan mekânlar, kapitalizm açısından, pazarda alınıp satılan soyut birer parsel ya da binadan başka bir şey değildir. Kapitalizm, yalnızca mekân üreterek değil, ama aynı zamanda mekân üzerinde üstün bir egemenlik kurarak ayakta kalmayı başarır. Kapitalist gelișme sürecinde doğal mekân sosyo-ekonomik şartlarda bir metaya dönüşmüștür (Lefebvre, 2014). Bu bağlamda kentlere yapılan gökdelenler, alışveriş merkezleri, lüks konutlar, oteller sermayenin kârını azamiye çıkartmak için yaptıkları yatırımların birer göstergeleridir (Harvey, 1997). Sermayenin kendi alışkanlığını kolaylaştırmak ve birikimi artırmak yönündeki eğilimi beraberinde yeni mekânsal düzenlemeler getirmekte, eski çevreler sürekli olarak bir değişme olgusu içinde bulunmaktadır (Yrrticl, 2003).

1980 sonrası Türkiye'de süreç (siyasal ve ekonomik) sermayenin büyük bir bölümünün birincil çevrim olan endüstriyel üretimden, ikincil çevrim olan, doğrudan üretkenliği olmayan gayrimenkul, finans ve turizm alanları gibi alanlara aktarılmasını ve sermayenin kentsel mekânların üretilmesi, yeniden yapılanması ve kentsel süreç üze- 
rinde belirleyici hale gelmesi şeklinde işler. 19901ı y1llarda orta ve büyük ölçekli sermaye gruplarının belirgin bir biçimde kentlere yatırım yapmasıyla alışveriş merkezleri, oteller ve iş merkezleri büyük kentleri hızla işgal etmeye başlar. Böylece Türkiye'de sermayenin giderek hegemonyasını kurduğu kentsel sürece girilir (Turhanoğlu, 2014). Sermayenin belirleyici olduğu kentsel süreçte mekân, politikacılar ve yöneticiler tarafindan kontrol altına alınan üretimin bir nesnesi olmaktadır (Lefebvre, 2014).

Tüm bu değerlendirmelerden sonra, EAA tarafindan tasarlanan The Museum Hotel Antakya, sosyo-ekonomik bağlamda semantik bir okumaya tabi tutulabilir.

The Museum Hotel Antakya, Antakya kenti, Haraparası bölgesinde 100 metreye 200 metre büyüklügünde bir alanda konumlanır. Necmi Asfuroğlu tarafından 2009 yılında, üzerine otel yapma niyetiyle satın alınan bu arazide yapılan öncül kazılar, önemli büyüklükte in situ Roma dönemi mozaiklerinin (Resim 5) yanında hamam, villa ve benzeri çok katmanlı buluntularını ortaya çıkarır. Asfuroğlu'nun otelin işletmesi adına sözleşme yaptığı Hilton markasının, asgari otel gerekliliklerinde en az iki bodrum katı ihtiyaç programında bulunmaktadır. Ancak, Arolat'ın (2019) anlatısıyla, kazdıkça her yerinden muhtelif buluntular çıkan arazi, Antakya Müzesi ve Koruma Kurulu tarafindan değerlendirmeye alınır. Akabinde başlatılan bilimsel kazı ekibinde Haluk Abbasoğlu, Hatice Pamir, Gülsün Tanyeli ve Sevim Aslan gibi isim- ler yer almaktadır. Söz konusu uzman ekip tarafından ortaya konan en önemli konu, tek bir bodrum katının dahi uygulanmasının mümkün olmadığıdır.

Emre Arolat'in bizzat davet edilmesi ile EAA, otelin projelendirme sürecini üstlenir. Firmanın önerisi, buluntuların takriben ortasından geçen ve geçtiği yerdeki her artifaktı silip süpüren dere yatağını tasarımın merkezine taşımaktır. Söz konusu dere yatağı temel alınarak, buluntuların arasına adeta bir yap-boz yerleştirircesine, 66 adet, 24 metre derinliğinde, 2 metre çapında kuyular açılır. 130 santimetre çapındaki içine beton doldurulmuş çelik kolonlar kuyulara sabitlenir (Resim 6).

Yapının ana strüktürü bu şekilde oluşturduktan sonra, EAA'nın son derece cüretkâr ancak bir o kadar da ilgi çekici önerisi devreye girer: otelin kesiti ters yüz edilir. Bu, zeminin pilotilerin üst noktasına taşınması suretiyle, giriş ve bodrum katlarda bulunması zaruri olan otel fonksiyonlarının söz konusu "yeni" zeminin üzerine konumlandırılması anlamına gelmektedir. Ezber bozuculuğu tartışmasız olan bu yaklaşım, mevcut buluntuları içeren orijinal zemin katını kamuya açık bir müze, yeni zemin ve eski zeminin arasında kalan boşlukların ise bir odalar istifi şeklinde kurgulanmasını ön görmektedir. Odalar, prefabrike elemanlarla, konstrüksiyon dişında oluşturulacak ve aralarında buluntuların izlenebileceği açıklıkların bırakılmasıyla yatay bağlantı yolları çevresine yerleştirilir. Söz konusu yatay bağlantı yolları, başka bir deyişle

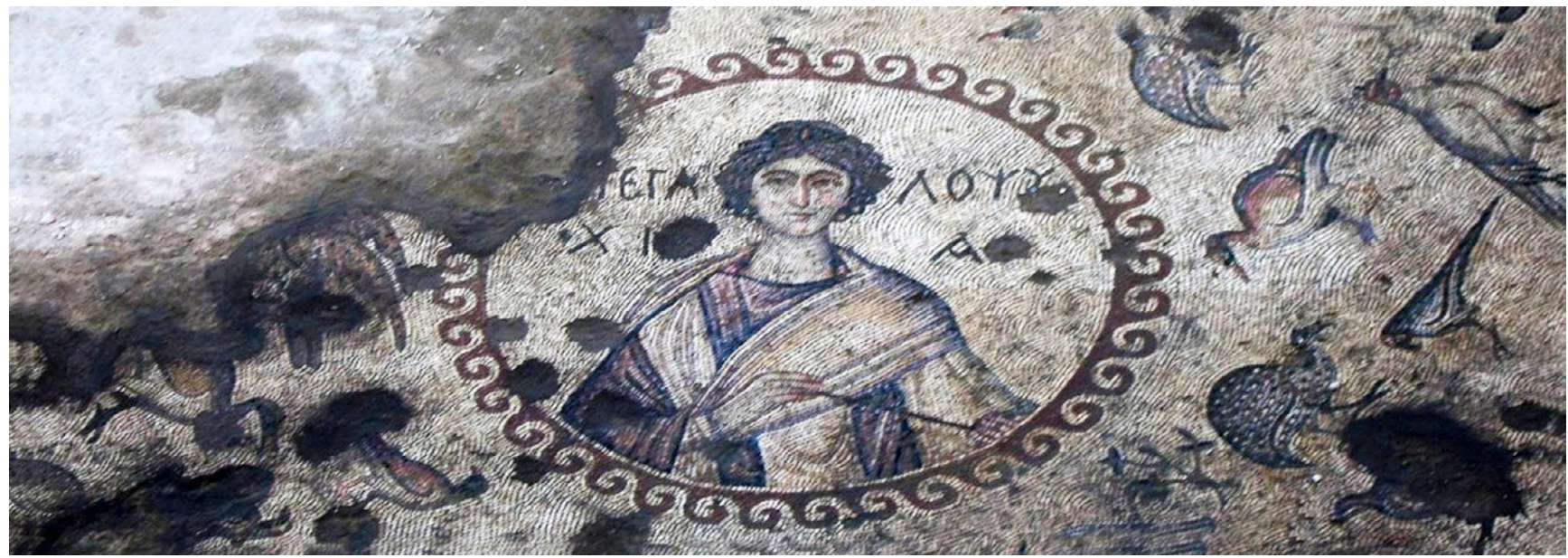




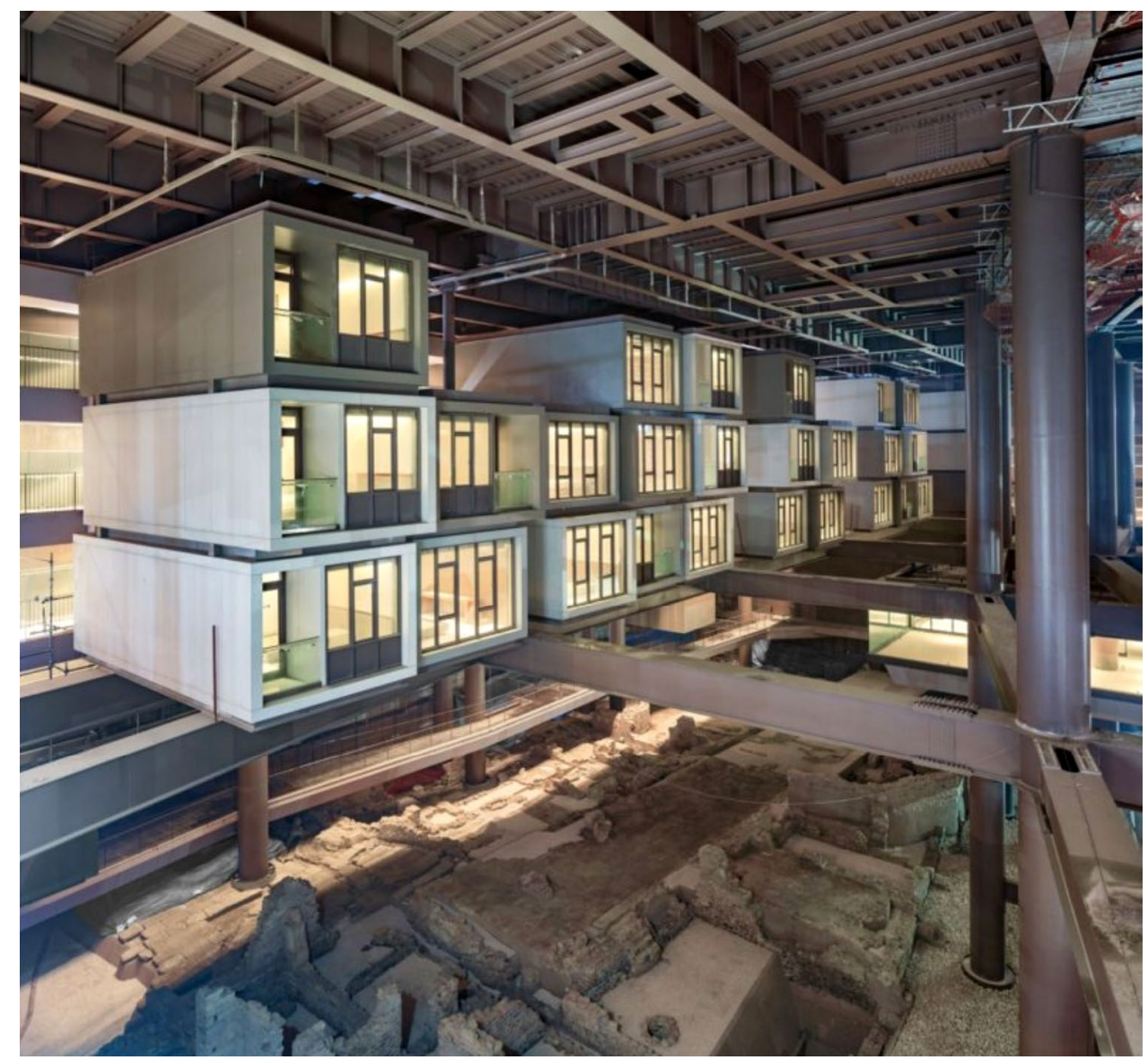

Resim: 7

The Museum Hotel Antakya'ya genel bakıs.
Resim: 6

şantiyeden görüntü.

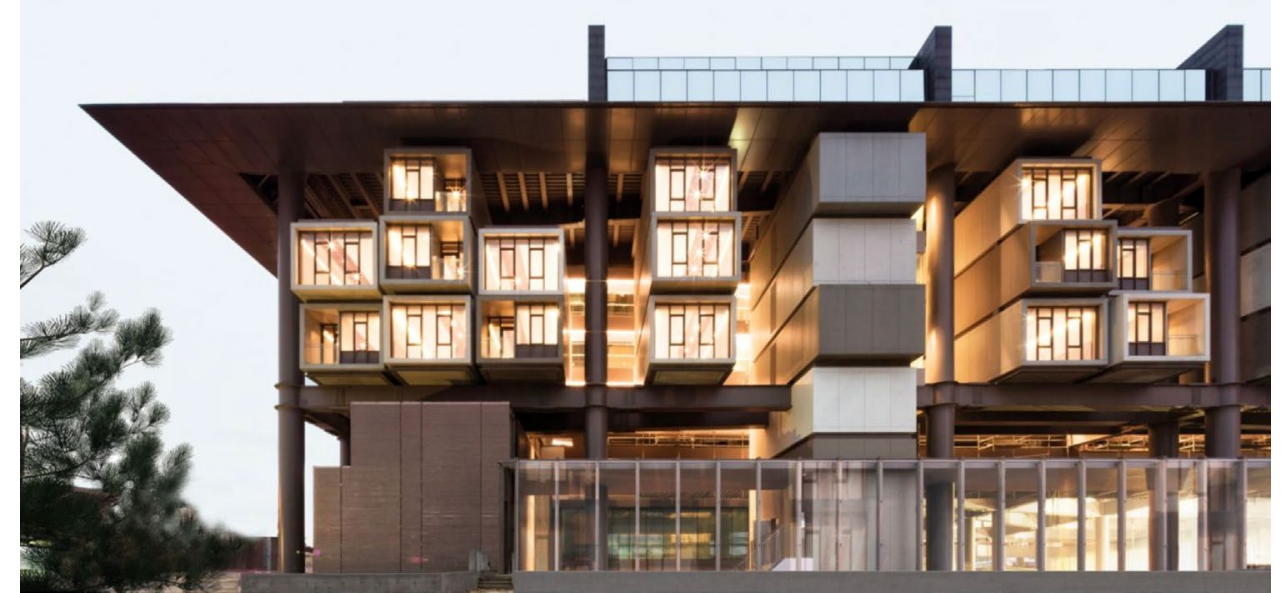

köprüler, buluntular doğrultusunda, onlara izlenecek alan bırakmak suretiyle yerleştirilir (Resim 7).

Arolat (2019), mimarlık alanının, kamusal ve özel alan arasında var olan tansiyon üzerine kurulu olduğunu ifade eder. Tüm unsurlar dikkate alındığında bu müze-otel, kısmen kamusa, kısmen özel alanlar tanımlarken bu tansiyonu yüksek tutar ve gerek müze ziyaretçileri gerekse otel müşterilerine söz konusu mekânlar arasında gidip gelirken biricik bir deneyim yaşama firsatı verir. 


\section{Sonuç}

Gerek EAA'nın web sayfasında gerekse bina ile ilgili çekilmiş muhtelif videolarda sürekli vurgulanan, binanın eşsiz bir fonksiyona sahip olduğu ve bu bağlamda dünyada bir benzerinin var olmadığıdır. Bu noktada yapılması gereken önemli bir değerlendirme, söz konusu müze-otelin aslında post-kapitalist çağın icat edilmiş bir fonksiyonu olduğu gerçeğidir. Neoliberal sistem, her ne kadar kamusal mekâna sayg1 duyma iddiasında olsa da 20,000 metre kare büyüklüğünde bir alanın, üzerindeki buluntuların değeri ne olursa olsun, rantsal niteliği göz ardı edilememiş, bu nitelik, bir star mimar üzerinden, uzmanların da afirmasyonu ile birlikte gerekçelendirilmeye çalışılmıştır. Söz konusu meşruiyet, buluntuların müzeye taşınmaması, aksine in situ varlıklarının korunarak kamuya açılması dahilinde iyice güçlenmektedir.

Emre Arolat'in mimari refleksi, Karatepe Saçakları müelliflerinin duyarlılığını büyük ölçüde anımsatan bir anlayış içerir. İki projenin müellifleri, yapılarında "yer"in izini sürerler. Projelerin ortak noktası olan ve alegorik olarak bir bağlamdan koparma görevi üstlenmesi mümkün bulunan piloti elemanları dahi, zarif veya kütleli fark etmeden, söz konusu izin vurgusuna boyun eğer. Başka bir deyişle bağlam, iki projede de ana kararları etkileyen en önemli etmen olarak deneyimleyicisinin karşısına çıkar. 50 yıl arayla yapılmış bu iki tasarımın sözü edilen ortak noktası, kuşkusuz, bağlamlarının gücünden kaynaklanmaktadır. İki kalıntılar öbeği de uzmanların görüşleri dahilinde müzeye taşınmamış, bunun yerine yerinde korunma yaklaşımı benimsenmiştir. Buna rağmen 50 yıl önce muhtelif bir tarihsel, arkeolojik kalıntının koruma yaklaşımı, onunla boy ölçüşmeyecek nitelikte bir üst örtüyken, günümüzde bu üst örtü, rantsal bir ürün olan dünya markası bir otele rahatlıkla evrilebilmiş, koruma kavramının bu zaman diliminde uğradığ semantik dönüşüm, neoliberal para politikaları üzerinden değerlendirilmeye açık hale gelmiştir.

Makalenin amacı EAA'nın mimari üretimini eleştirmek ya da neoliberal sistemin getirileri veya götürüleri üzerine toplumsal içerikli bir bakış açısına odaklanmaktan çok uzaktır. Özellikle vurgulanmak istenen, mimari refleks benzer olsa dahi 50 yıl içerisinde mimarlığın eklemlendiği mekânsal dönüşümün; saçakların otele çevrilmesinde tezahür ettiği gerçeğidir. Yani 1950'li yılların, saçaklardan oluşan koruma üst örtüsü, 21. yüzyılın başında yerini icat edilmiş bir fonksiyona, bir müze-otele bırakabilmiştir. Mimarlık tarihini nesnelerinin uğradığı anlamsal dönüşümler bağlamında böylesi bir karşılaştırma, meslek literatürü için önemli veriler teşkil edecektir• 


\section{Kaynakça}

Akın, G. (2004). Brütalizm, Mir Modernist Üslup. Betonart, 8, 2-4.371

Arolat, E. (2019, Temmuz 22). Emre Arolat Antakya Müze Otel'in Anlattyor [Video]. YouTube. https://www. youtube.com/watch? $\mathrm{v}=\mathrm{H} 0 \mathrm{DP} 3 \mathrm{zdU} 0 \mathrm{rc} \& \mathrm{t}=2 \mathrm{~s}$

Burkut, E. B. (2019). Türk Evinin Karakteristik Üslubu Saçak. Toki Haber, 2, 50-54.

Ceylan E. (2014). Çatıyı Yer[in]e Koyamamak veya Adem'in Karatepe'deki Evi Üzerine. Betonart, 40, 30-35.

Demirgüç, U. (2006). Mimarlıkta Eleştirel Bölgeselcilik ve Turgut Cansever (Yayımlanmamış yüksek lisans tezi). İstanbul Teknik Üniversitesi, İstanbul.

Erkol, İ. (2016). Türkiye Mimarlığında Modernizmin Revizyonlarl (1960-1980) (Yayımlanmamıș doktora tezi). İstanbul Teknik Üniversitesi, İstanbul.

Harvey, D. (1997). Postmoderniğin Durumu. İstanbul: Metis Yayınları.

Hasol, D. (1998). Ansiklopedik Mimarlık Sözlüğ̈̈. İstanbul: Yapı Endüstri Merkezi Yayınları.

Köksal, A. (2016, Ağustos 1). Karatepe Saçakları ve Müelliflik Sorunu. Mimarizm Mimarlık ve Tasarım Yayın Platformu. https://www.mimarizm.com/kose-yazilari/ karatepe-sacaklari-ve-muelliflik-sorunu_126312

Kurtar, S. (2013). Mekânı Yaşamak: Lefebvre ve Mekânın Diyalettik Oluşumu. Academia. https://www.academia.edu/2945638/Mekânı_Yaşamak_Lefebvre ve_Mekânın_Diyalektik_Oluşumu_TüCAUM

Lefebvre, H. (2014). Mekânın Üretimi. İstanbul: Sel Yayınları.

Özer, B. (2000). Kültür, Sanat, Mimarlık. İstanbul: Yapı Endüstri Merkezi Yayınları.

Sayın, N. (2004). Karatepe'de Zaman. Betonart, 7, 27-32.

Tanyeli, U., Yücel A. (2007). Turgut Cansever Düşünce Adamı ve Mimar. İstanbul: Garanti Galeri \& Osmanlı Bankası Müzesi Yayınları.

Turhanoğlu, A. (2014). Kentsel Mekânın Üretim Sürecinde Tarihsel ve Kültürel Miras, folklor/edebiyat, 20 (7-8), 71-82.

Uğurlu, Ö. (2013). Neoliberal Politikalar Ekseninde Türkiye'de Kentsel Mekânın Yeniden Üretimi. Türk Tabipler Birliği Mesleki Sağllk ve Güvenlik Dergisi, 1-2, 2-12.

Yirtıc1, H. (2003). Modern Kapitalist Toplumlarda Mekân Üretimi Hipermarketler Özelinde Tüketim Mekânlarının Altyapısal Dönüşümü ve Yeni Bir Mekân Epistemolojisi Tartışması (Yayımlanmamış doktora tezi). İstanbul Teknik Üniversitesi, İstanbul. 